УДК 37.016:808.55]:81’27](045)

ORCID: https://orcid.org/0000-0002-5017-0126

Сухорукова Карина Сергї̈вна,
аспірантка кафедри сценічної мови. Київський
національний університет театру, кіно і
телебачення імені І. К. Карпенка-Карого, Київ

Karyna Sukhorukova, postgraduate student. Kyiv National

I. K. Karpenko-Karyi Theatre, Cinema and Television University, Kyiv

\title{
ВИКОРИСТАННЯ РЕГІОНАЛЬНО-МОВЛЕННЕВИХ ВИСЛОВЛЮВАНЬ У НАВЧАЛЬНІЙ ПРАКТИЦІ
}

\begin{abstract}
Анотація. Розглянуто використання регіонально-мовленнєвих висловлювань у навчальній практиці майбутніми акторами драматичного театру. Вказано на доцільність освоєння літературної вимови як чинника у формуванні трансформаційних перетворень в усній українській сценічній мові. Сформульовано визначення «Регіонально-мовленнєві висловлювання» в контексті слова на сцені та запропоновано науково-творчий метод щодо оволодіння вимовою з діалектною лексикою. Зроблено оглядовий аналіз мовного образу вистави «Буна», а також деталізований розбір фонологічного портрета на прикладі аналізу роботи виконавиці головної ролі.

Ключові слова: навчальна практика, майбутні актори, вимова, регіонально-мовленнєва специфіка, мовний портрет.
\end{abstract}

Постановка проблеми та актуальність дослідження. Останнім часом періодично виникає потреба в переформуванні методів у галузі оволодіння сценічно-художнім словом у процесі підготовки майбутніх акторів драматичного театру в мистецьких вищих навчальних закладах освіти. Це пов'язано із запитами, прогресивнотенденційним розвитком сучасної сценічної практики. Особливості виголошуваного тексту ролей у виставах можуть бути в розрізі не збігатися зі сталими понятійно-категоріальними підвалинами висловлювань, суперечити стандартизованим нормам української мови.

Вітчизняна класична і сучасна драматургія наштовхує режисерів на реалізацію творів із регіонально-мовленнєвою специфікою, що зумовлює використання різноманітного арсеналу акторських засобів виразності: мовно-голосових прийомів, психологічно-внутрішньої гнучкості, особливого пластичного малюнка тощо. Аналіз вистав київських театрів дає можливість стверджувати, що народнопоетичні твори ускладнюють постановочний процес для виконавців, хоча і пожвавлюють публічний інтерес до різ- номанітного репертуару, сприяють завоюванню глядачів.

3 огляду на це можна стверджувати, що актуальність теми дослідження обумовлена вимогами сучасної сценічної практики. Багатовекторність професійної оснащеності акторів драматичного театру допоможе збагатити варіативність умінь і навичок мовно-голосового апарату, що в майбутньому формуватиме деталізований мовний портрет персонажів.

Метою статmi є виявлення закономірностей між навчальною й театральною практикою в опануванні регіонально-мовленнєвою специфікою та їі доцільного використання в освітньопедагогічному процесі.

Аналіз сучасних досліджень $і$ публікацій. Варіативність у набутті й застосування вимови з регіонально-мовленнєвими особливостями лімітовано проаналізована українськими фахівцями-практиками зі сценічної мови. Дослідники ж у царині діалектології, зокрема: М. Жовтобрюх, Б. Кобилянський, О. Потебня та ін. систематизували теоретичні надбання, науково опрацювали на мовознавчому поприщі видозміни українського слова 
в різних регіонах нашої країни. Грунтовні джерельні пропозиції (навчально-методичних збірників, монографій, методичних посібників тощо), які б мали емпіричний характер щодо оволодіння діалектною сценічною вимовою, наразі наявні в досить обмеженому форматі, а фактично відсутні. Впродовж тривалого часу українські фахівці у галузі сценічної мови зосереджували свою увагу переважно на аналізі процесу уодноманітнення загальновживаних слів, мовних конструкцій, на оволодінні зовнішньою акторською технікою та внутрішніх пристосуваннях у розповіді. Втім, слід зазначити, що водночас пропонувалися й нові прийоми роботи над словом, що в своїй сукупності призвело до створення спеціальних навчально-методичних видань. У цьому контексті закцентуємо вагомість наукових праць Л. Сокирко, Д. Ревуцького, С. Кошачевського, І. Горянської, Н. Стихун, Н. Грицан та ін. Разом із тим, методики науково-мистецького спрямування, що фундаментально розкривали б усі художньовиконавські аспекти з залученням діалектної лексики, а також допомагали комплексному оволодінню прийомами говіркового звучання в класі сценічної мови, поки що не існує. Цей факт, безперечно, спонукає до вивчення даного наукового питання у вищих мистецьких закладах освіти. Слід наголосити, що окремі твердження та тези щодо відхилень від норм сучасного українського мовлення, зокрема, діалектного звучання в фонемах, говіркового наголошення слів входять у коло науково-педагогічних інтересів фахівця-мовника в галузі сценічної мови Т. Кобзар. Враховуючи, що від того, наскільки позиційно правильно й акустично чітко голосні озвучені рухомими м'язами мовного апарату, залежить унормовано-літературна вимова чи анормальність мовлення акторів-виконавців. У своєму дослідженні «Сценічна мова: техніка мовлення» Т. Кобзар доречно вказує на те, що діалектне, здавлене звучання голосних $a$, $o$ та плоска, говіркова вимова $e$ (окрім випадків у театрі, коли це є доречним для драматургіi) (Кобзар, 2013, с. 98-99) - показова особливість нетипового звуко-вимовного існування. Крім того, фахівець-практик зауважує, що характерні порушення діалектного напряму стосуються і словесних наголосів. Ці два компоненти мають лідерські позиції серед інших, що допомагають точно визначити діалектні відхилення у вимові. Однак спеціалістмовник не вказує на оволодіння регіональномовленнєвою специфікою в навчальній практиці, що породжує вивчення цієї наукової квестії.

Водночас слід зауважити, що проблематика цілеспрямованої словесної канви постави: дикційної розбірливості, голосового посилу, швидких пере- ключень у мелодико-інтонаційному ключі, оживлення просторічних слів у достовірну виконавську форму - існує від зародження національного театру. Так, зокрема, один із його зачинателів М. Кропивницький визнавав, що загальнонародна мова має стати культом, національним надбанням й бути поширеною в широкі глядацькі маси не лише на території нашої країни, а й далеко за іiі межі. Надалі такі міркування корифея глибоко укорінилися й вплинули на світоглядні переконання його послідовників.

Про використання мовлення із елементами діалектної лексики в умовах театральної практики здебільшого йдеться в наукових публікаціях зарубіжних спеціалістів. Приміром, Л. Култаєва, М. Оссовська, І. Промптова, В. Чепуріна та ін. розглядали використання говіркової вимови в межах сценічного майданчика як один із засобів створення довершеного образу вистави. Грунтовно розглянуто $з$ точки зору навчально-театральної практики та детально висвітлено використання діалектної лексики в мистецько-освітньому обігу на сторінках дисертаційного дослідження петербурзького викладача, завідувача кафедри сценічної мови Російського інституту сценічних мистецтв - Л. Алфьорової. Фахівець-практик у своїй змістовній праці вперше торкнулася теми, що потребує наукового вивчення $з$ точки зору анормальності художнього слова - як елемента навчального процесу, так і втілення його в сучасній театральній практиці. А саме проблематиці, що напряму пов'язана 3 говорами в сценічній мові, їхньому доречному використанню чи, навпаки, запобіганню в освітньому й сценічному досвіді. В цій науковій праці, з одного боку, проаналізовано процес усунення ознак говіркової вимови, що індивідуально виражені в мовленні майбутніх акторів впродовж навчання, а 3 іншого - вживання виконавцями діалектної лексики в озвучуванні текстових реплік у сценічній практиці. Авторка розлого схарактеризувала різницю між унормовано-літературною вимовою та тією, що поза стандартизованою нормою, підтвердила доцільність вивчення й раціонального використання в освітньому процесі просторічного мовлення як атрибуту сценічного образу.

Вищезгадані наукові дослідження свідчать про вагомі здобутки в галузі мовознавства у сфері навчально-театральної практики. Звичайно, ïх потрібно примножувати, розвивати і впроваджувати в програмне забезпечення вітчизняних вищих закладів мистецької освіти. Тут потрібно враховувати, що досягнення високопрофесійної акторської майстерності у виставах фольклорис- 
тичного характеру можливе лише за умови набуття відповідних навичок із діалектним ухилом у класі сценічної мови.

Виклад основного матеріалу. Сценічна мова посідає чільне місце серед профілюючих дисциплін у процесі підготовки, подальшій професійній практиці акторів драматичного театру. Однак, звичайно, ця дисципліна - не єдина складова у досягненні достеменного, органічного існування в запропонованих обставинах. Завдяки симбіозу різних фахових та загальноосвітніх предметів вдається отримати варіативність нових навичок і вмінь, що згодом ефективно працюють на отримання остаточного результату. Характерна специфіка сценічної мови полягає в тому, що виконавець вголос вимовляє не власні думки, а авторські, які здебільшого спрямовує на партнера: на сцені, а також й у глядацький зал. У рольовій моделі перебування актор стикається з багатоманітними стилями мови, жанровими особливостями, котрі існують у п’єсі чи художньо-літературній інсценівці. Ось чому в особистому «мовленнєвому фонді» виконавця мають фігурувати варіації дикції, голосу; орфоепічні, фонологічні та мелодико-інтонаційні зміни, які потрібні для утворення вимовленоозвученої характеристики образу.

У мові кожної людини закодовано її єство, яке актор повинен максимально точно й органічно відтворити, вийшовши на кін. Завдання полягає в тому, аби переконливо зіграти мирянина із Харкова, Чернігова, Львова, Одеси чи селянина з будь-якого іншого регіону. Ми цілком поділяємо міркування Л. Алфьорової про те, що актор повинен уміти говорити мовою персонажа. Мовна особистість актора - унікальне явище, обумовлене феноменом театру як мистецтва перевтілення (Алфьорова, 2006, с. 100). Виконавець постає співавтором драматурга та режисера, генеруючи мертвий написаний текст у візуально-пластичне втілення, спираючись на дієве словесно-органічне оформлення. При цьому чимале значення в практичнотеатральній дійсності має процес перетворення творчого індивідууму на сценічного героя, що відбувається, по-перше, за час застільнорепетиційного періоду, по-друге, щоразу, коли актор виходить на кін.

Актуальність проблематики загострюється ще й тим фактом, що в українській навчальнотеатральній практиці фактично немає методики оволодіння регіонально-мовленнєвою специфікою в межах освітніх програм. А відповідно - вони не мають змоги делегуватися надалі в постановочний процес. У народнопоетичних виставах виконавці ролей обмінюються між собою думками-репліками, що називаються «регіональномовленнєві висловлювання». Це фрази, що містять ознаки діалектної лексики: відхилення від правильної фонетичної вимови, нетипові дикційні та мелодико-інтонаційні виявлення, голосові переключення, паралінгвістичні особливості в озвученні акторами авторського тексту в контексті слова на сцені.

Майбутнім акторам драматичного театру варто знати і вміти застосовувати у спектаклях із неунормовано-літературною мовою такі теоретикопрактичні навички: 1) опрацьовувати семантичний розбір реплік; 2) користуватися подовженим озвученим видихом; 3) витримувати лексикосемантичні та фонетичні погрішності; 4) чітко реконструювати складні збіги звуко-комплексів фраз; 5) віднаходити інтонаційні моделі; 6) дотримуватись темпо-ритмічних метаморфоз; 7) утримувати звуко-висотні та динамічні модуляції; 8) вдаватися до пластичних перетворень. Користатися переліченими принципами в сценічній діяльності можливо лише за наянвості фахової готовності, а також мотиваційного переконання до пізнання нового на шляху реалізації ролі в виставах із регіональномовленнєвою специфікою. Тож насамперед слід докладно оволодіти цими навичками, щоб надалі їх поглиблювати та удосконалювати.

Передусім слід зауважити, що оволодіння регіонально-мовленнєвою специфікою може відбуватися через практичні, індивідуальні заняття зі сценічної мови та на навчально-театральному майданчику в закладі вищої освіти. Впродовж підготовки фахівців-акторів драматичного театру $є$ можливість оволодіти азами діалектної вимови як у класі сценічної мови, так і в класі майстерності актора. Таким чином, грунтовно фіксуються та остаточно закріплюються отримані навички не лише в тренажній формі, художньолітературних композиціях, а й у пробних етюдах, уривках з вистав, у навчальних спектаклях. У такий спосіб підвищується ефективність у досягненні цілісного результату в умовах досягнення заключної мети - вмінні працювати з будь-яким текстом і здатність реалізувати його на сцені. Насамперед, слід зосередити свою увагу на засвоєнні основоположних засад із техніки мови: опануванні змішано-діафрагмального типу дихання, відшліфуванні дикції в різних модифікаціях звучання, культивуванні голосових можливостей, студіюванні правильної орфоепічної вимови. Згадані положення в компіляційному поєднанні підведуть акторів-початківців до повнозвучного роз- 
криття словесної канви, емоційної проникливості в сюжетно-композиційний вимір вимовленого тексту. Надалі слід поетапно просуватися в підборі більш складних поставлених завдань, що провокуватимуть до комбінованого пізнання трансформацій. Якщо на початках навчання одразу занурити студентів-акторів у процес оволодіння регіональномовленнєвою специфікою, вірогідність продуктивного засвоєння пропонованого матеріалу мінімальна. Основний контингент вступників на акторські курси не володіє стандартизованими нормами літературної вимови. Водночас - переважна більшість майбутніх митців театральної справи - це мешканці різних областей України. Відповідно, вони $\epsilon$ носіями несхожих між собою діалектних груп української мови: південно-східного, північноукраїнського (поліського), південно-західного наріччя. Тому слід спочатку навчитися говорити безпомилково, відповідно до встановлених загальних правил. Крім того, потрібно розкрити індивідуальну унікальність голосу, навчившись правильно дихати, поліпшити дикцію - активізувати роботу всіх складових компонентів для повнозвучності мовно-голосового апарату. Після отримання позитивних результатів в основоположних критеріях набуття навичок, виникне творчий стимул в оволодінні унормовано-літературною вимовою: освоєнні морфологічних, лексичних, фонетичних нюансів i т. ін. Далі студентів-акторів доречно долучати до теоретико-практичного освоєння оглядовоуніверсальних засад своєрідної вимови, а також до збагачення діалектного лексикону. Запропонований принцип роботи допомагає послідовно осягнути та зафіксувати навички з регіонально-мовленнєвою специфікою, що в майбутній професійній діяльності сприятиме органічно-достовірному втіленню ролей із елементами говіркового мовлення всіма учасниками вистави 3 фольклорною канвою. До такої думки схильна й науковець-практик Л. Култаєва, яка стверджує: говір якісно проявиться в спектаклі лише за умови гарного володіння акторами літературною вимовою (Култаєва, 2002, с. 110). Іншими словами, поетапно рухаючись - від літературної вимови до діалектної, можливо досягнути певного відчутного результату. Методологічно вивірений шлях - від полегшених завдань, вправекспериментів до ускладнених по лінії не лише зовнішньої, а й внутрішньої техніки - сприятиме систематизації знань на шляху здобуття професійної компетентності.

Головне призначення дисципліни «Сценічна мова» - підготовка майбутніх акторів у площині словесної майстерності. Опрацювавши планові розділи предмету та стратегічно продумавши навчальні концепції курсу, слід проводити пошуковоекспериментальну діяльність у мовному оснащенні студентів і в процесі викладання дисципліни «Майстерність актора». Відповідно, це $є$ своєрідні заняття-спроби, що обумовлюють творче перебування молодих акторів спочатку в навчальному, а в найближчій перспективі й у професійному театрі. Відбір навчального матеріалу для таких занять зі сценічної мови (вправ, текстів) поділяється на сектори:

- м'язові навколо гортані, тілесні затиски (вміння керувати градаційною амплітудою затискрелаксація, усунення перебільшеної напруженості організму);

- дихання (зміцнити, інтенсифікувати роботу змішано-діафрагмального поясу);

- дикція (спровадити якість вимови до еталонних норм);

- голос (знаходження індивідуальної тембрової гами, розбудова персоналізовано для кожного студента-актора діапазонів);

- колективна творчість (поступ до гуртової роботи, вміння зосередитись на самостійному аналізі матеріалу: 3'ясування смислової думки, перевірка акустичних, акцентологічних наголосів і т. ін.).

Очевидно, що обрані пункти роботи мовного аспекту надалі ефективно допоможуть у репетиційних періодах для створення сценічних. На основі вищезгаданих чинників відбувається творчопошуковий відбір навчальних вправ-завдань із регіонально-мовленнєвими особливостями:

- ліквідація напруженості м'язів мовноголосового апарату (усунення тілесної натуги в фонаційному процесі);

- акт дихання (опрацювання різноманітних темпо-ритмічних фігур дихальних хвиль у доборі та видиханні повітря);

- дикційні трансформації (освоєння нових звуко-комплексів діалектного характеру: в словах, фразеологічних висловлюваннях, авторсько-народному тексті);

- метаморфози голосу (розвинення трьох діапазонів, напрацювання голосової міцності, тембрового звучання);

- майстерність курсової творчості (досягнення ансамблевості звучання, а також рухливої сценічної дії в розповіді з діалектною лексикою). Знайдені засади рекомендуються як методологічних спосіб в оволодінні нетиповими мовними професійними навичками з помітними відхиленнями від літературної вимови звучання. 
Отож пропонується до створених і зазначених вище позицій по одній вправі-прикладу:

- Вправа № 1. «Переляк»: вихідне положення стоячи, ступні на ширині пліч, паралельно одна одній, спина рівна, грудна клітка вперед. Фіксований видих. Безшумний короткий вдих через ніс (на рахунок 1) одночасно затиснути всі м'язи тіла (рахуємо подумки до 5), видих робимо зі звуком «х», м'яко опустивши при цьому розслаблений тулуб вниз до підлоги. Стежити за балансом між напругою та релаксацією тіла. Виконати: 4 рази поспіль.

- Вправа № 2. «Графіті»: розміститися курсом у формі клину в межах аудиторного майданчика. За допомогою фонеми «ф» у повітрі «намалювати» назву вищого навчального закладу освіти - КНУТКіТ імені I. К. Карпенка-Карого. Стежити за рівномірним видихом, підключати тілесну пластику до звукового наповнення. Виконання вправи вважається завершеним, коли всі літери звуко-вимовлені.

- Вправа № 3. «Варіації приголосних звуків»: актори-початківці діляться на три дрібногрупові частини курсу. Кожна отримує завдання створити етюди-замальовки на довільні теми, використовуючи при цьому виключно приголосні фонеми в багатоманітних трансформаційних варіантах, що притаманні говіркам.

- Вправа № 4. «Телеграма»: актори-початківці розташовуються півколом у межах аудиторного простору. По двоє поступово просуваються вперед до глядача й одночасно вимовляють у наспівно-розмовній манері звукоряди голосних фонем із кожного наріччя та говорів на примарному тоні. Кожна гамма діалектного вокалізму лунає впродовж двох секунд. Промовляються звуки: південно-східного наріччя: i, и, e, a, o, y; південно-західного наріччя: i, и, е, a, о, у; голосні, що належать до карпатського говору: i, и, e, a, o, ы, у, середньо-закарпатської говірки: i, и, е, a, o, ы, у, ӱ; поліського (північноукраїнського) наріччя: наголошений вокалізм - i, и, ie, e, a, o, уо, теж i, и, е, a, o, уо, у; ненаголошений вокалізм - i, и, е, a, o, у. Виконання вправи вважається завершеним, коли всі учасники колективного тренінгу попарно відтворили весь звукоряд.

- Вправа № 5 «Проза $з$ діалектною лексикою»: актори-початківці обирають твори авторів, які є представниками певного українського наріччя та індивідуально розповідають їх, демонструючи вміння та навички мовного існування в матеріалі. Комплексна вправа, що сприяє: урізноманітненню та розкриттю української мови в художньому виконанні, надає можливість продемонструвати вправність органічного використання діалектного слова.
Новоутворений структурний план постає як варіант із тренінгових вправ, що може гарантувати комбіноване оволодіння навичками регіональномовленнєвої вимови. Пропонований науковотворчий метод роботи полягає, по-перше: в поетапному практичному набутті основоположних засад із техніки мови; по-друге, вводити на попередньо засвоєній базовій оснащеності до тренінгової форми вправи-завдання з елементами діалектної лексики. До того ж слід пам'ятати під час практикумів й про «акторське ввімкнення» у вправахекспериментах. Завдяки ним накопичується вміння миттєво відтворити той психо-емоційного стан, що його вимагають запропоновані обставин. А це $\epsilon$ найважливішим моментом для подальшої професійної діяльності. Такий напрям навчального процесу, на наш погляд, заслуговує на особливу увагу 3 метою подальшого вивчення, заглиблення в матеріал і запровадження його в практику викладання дисципліни «Сценічна мова» в вищих мистецьких закладах освіти.

Показовим є той факт, що на київській театральній сцені втілено чимало постановок, які вбирають багатогранну красу українського слова. Цікаво й те, що переважна більшість із них створювалася і набула остаточного вигляду безпосередньо в процесі роботи. Ми звернемо увагу на спектакль випускного акторського курсу під орудою О. М. Шаварського, що народився на навчальній сцені Київського національного університету театру, кіно і телебачення імені І. К. КарпенкаКарого та незабаром увійшов до репертуару Національного академічного драматичного театру імені Івана Франка. Це постановка режисера Давида Петросяна «Буна» за п’єсою сучасної авторки Віри Маковій. Цей драматургічний твір містить головоломний психологічний пласт сімейних, міжлюдських стосунків, що розкриваються засобами словесної кантилени буковинського діалекту. Враховуючи авторську сюжетну концепцію, режисер прийняв рішення винести на глядацький розсуд такі теми: розбіжність людських цінностей, сімейні непорозуміння, проблеми заробітчанства тощо. На превеликий жаль, на етапі задуму та в процесі втілення вистави 3 характерними рисами буковинського діалекту не було застосовано методики в галузі сценічної мови для оволодіння регіонально-мовленнєвою специфікою. В результаті, щоб достеменно точно відтворити мовний портрет свого героя та простежити психологію поведінки мешканців цього регіону, актори-студенти здійснили місячну експедиційну поїздку до одного із сіл Чернівецької області. Вони стежили за 
поведінкою місцевих жителів, їхніми повадками, вподобаннями; вивчали побут, хатню обстановку i т. ін. Крім того, заточували індивідуальний фонематичний слух, вслуховуючись в особливості вимови та звукоутворення висловлювань, фіксували звукосполучення буковинських вигуків, фраз, прокльонів, молитов, а також збирали автентичні пісні. Завдяки такому фундаментальному підходу, зокрема й тривалому застільному періоду кожному виконавцеві вдалося органічно відтворити образ свого сценічного героя у психо-емоційній забарвленості та мовленнєвій самобутності.

На основній сцені навчального театру Київського національного університету театру, кіно і телебачення імені І. К. Карпенка-Карого студентиактори сформували цілісні емоційно-проникливі, візуально-пластичні та мовні портрети своїх героїв, які надалі знайшли своє сценічне продовження вже у професійному театрі. У даному разі науковотворчий інтерес викликає саме вербальна специфіка акторського перевтілення. До прикладу, взявши за взірець вживання діалектної (буковинської) вимови, реалізуємо фонетичний розбір головної дійової особи Буна у виконавиці актриси Христини Федорак:

1) Специфічні трансформачії вимови в окантовці українського вокалізму: а) заміна останнього голосного И на I (ході, пристолі, святкі тощо), б) єкання - підміна голосного Е на $€$ (такє, полє і т.п.), г) укання - зміна О на У (пуїхав, пурізані й под.) в) метаморфози йотації звуків - підміна Я на $€$ (вєсіллє, промовлєючи, свєтошний, жіттє тощо);

2) Особливості дикиії в межах українського консонантизму: а) сигматизм - заміна С на Ш (приштолі, ошь і т. ін.), б) шокання - заміна Щ на Ш (шо, шоб тощо), в) підміна в дієсловах закінчення ТИ- на -ТЬ (співать, робить і т.п.);

3) Порушення ізохронності в повноцінному озвученні слова: а) не вимовляння Г (цьоо, нічьоо, всьоо), б) втрата кінцевого приголосного 3 (зара);

4) Використання інтонаційно-мелодійних градаиій говіркової вимови: а) голосова амплітуда в інтервалі власного звуко-висотного діапазону 3 домінантою верхнього регістру; б) фрагменти мовлення з елементами парної (в партнерському поєднанні) кантилени звучання;

5) Говіркова якість вимови в площині ритмомелодики: а) тахілалія - прискорення в озвученні тексту; б) вокальна позиція артикуляції голосних звуків Е й А впродовж акту фонації;

6) Метаморфози акустичних наголосів: a) недотримання унормованих орфоепічних наголосів (а́ле, кида́ю, живе́те, ме́не, вне́сла тощо);
7) Регіональні лексико-семантичні чинники вимови: а) вживання фразових одиниць південнозахідного наріччя (файного, шляк би вас всіх трафив, стидно, видіти, нема дурних, ніц і т. ін.), б) використання слів-паразитів - багаторазовий вербальний рефрен (виділа, срака, нє, такє тощо).

На камерній сцені Національного академічного драматичного театру імені Івана Франка вже дипломованим акторам довелося знаходити й удосконалювати мовно-голосові пристосування, вдаватися до внутрішньо-психологічної трансформації; інакше впроваджувати пластичні, мізансценічні перебудови, щоб досягнути єдиного ігрового ансамблю у виставі. Озвучення текстових реплік усіх виконавців ролей передбачало: вироблення півторагодинної голосової стабільності, органічного просторічного говоріння: динамічного зменшення / збільшення гучності, пришвидшення / сповільнення темпу розмови, належним чином чутно мовити на тлі фонограмної мелодії в межах просторово-сценічного майданчика і тому подібне.

Висновки. Підсумовуючи викладене, слід наголосити, що існує нерозривний зв'язок між навчальним процесом у підготовці майбутніх акторів і затребуваністю на театральному кону спеціалістів iз багатогранними фаховими навичками. Сучасний попит на вистави фольклористичного характеру висуває нові вимоги до мовленнєвої компетенції виконавців ролей як за час навчальної підготовки, так і впродовж професійної діяльності. Вистудіювати регіонально-мовленнєву специфіку можливо шляхом освоєння літературної вимови. Завдяки базовим зовнішнім технічним мовно-голосовим аспектам: опануванню тілесної свободи, освоєнню правильного типу дихання, набуттю навичок із чистоти дикції, голосоутворюючим факторам - можливо сконструювати нову модель мовної поведінки. А потім розвивати її по лінії психо-емоційної внутрішньої скерованості в озвученій формі. Пропонований науково-творчий метод опрацювання діалектної вимови містить варіативність у розширенні арсеналу словесної майстерності акторівстудентів та діючих артистів. Різновид роботи над озвученням неунормовано-літературних текстів окреслюється надзавданням, наскрізною дією, творчо-художньою метою навчальної практики.

Здійснений із фонетичної точки зору аналіз мовленнєвої характеристики головної героїні вистави «Буна», засвідчує актуальність і перспективність уведення спеціального курсу, що містить основи регіонально-мовленнєвої специфіки висловлювання. 
Практично вивірений науково-творчий метод роботи над регіонально-мовленнєвим висловлюванням має стати стимулом для розвитку новоутвореної технологічної моделі оволодіння українською сценічною мовою.

\section{Джерела та література}

Алфёрова, Л. (2006). Проблема говоров в сиенической речи: дисс. ... канд. Искусствоведения: 17. 00. 01 «Театральное искусство». СПб. гос. академия театрального искусства. Санкт-Петербург.

Кобзар, Т. В. Сценічна мова: техніка мовлення. Черкаси: видво Ю. А. Чабаненко, 2013. С. 98-99.

Култаева, Л. (2002). Диалекты как средство создания художественного образа. Искусство и искусствоведение: теория и опыт (Сиеническая педагогика): Сборник. Кемерово. Вып. 1. С. 107-111.

\section{References}

Alferova, L. (2006). Problema govorov v stsenicheskoy rechi [The problem of dialects in scenic speech: diss.] ... Cand. Art Studies: 17. 00. 01 «Theatrical Art». St. Petersburg. state Academy of Theater Arts. St. Petersburg. [in Russian]

Kobzar, T. V. (2013). Stsenichna mova: tekhnika movlennia [Stage language. Speech technique]. Cherkasy: vyd-vo Yu. Chabanenko, pp. 98-99. [in Ukrainian]

Kultaeva, L. (2002). Dialektyi kak sredstvo sozdaniya hudozhestvennogo obraza [Dialects as a means of creating an artistic image]. Art and art history: theory and experience (Stage pedagogy): Collection. Kemerovo. (Issue. 1), pp. 107111. [in Russian]

\section{Karyna Sukhorukova}

\section{Using Regional Speech Expressions in Training Practice}

Abstract. The article examines use of regional-speech expressions in training practice for future actors of dramatic theatre. There is pointed out the expediency of mastering literary pronunciation as a factor in transformational changes in the oral Ukrainian stage language. It is formulated the definition of «Regional speech expressions» in a word context on the stage and it is proposed a scientific and creative method for mastering pronunciation with a dialectal vocabulary. It was made a review analysis of the linguistic image of the play «Buna» as well as a detailed analysis of the phonological portrait on the example of the lead actress.

Key words: training practice, future actors, pronunciation, regional-speech specifics, language portrait. 